\title{
ABOUT A "PROPER LAW OF A (RESTITUTIONARY) REMEDY"
}

\author{
Olusoji Elias*
}

The term "proper law" is a concept normally used to determine the choice of applicable law in transnational contract disputes. It can also apply by analogy to other types of issue arising in conflict of laws cases, which are also subject to choice-of-law method. When it does apply, for example, in finding whether there has been an unjust enrichment and whether consequently there ought to be restitution, its hallmark is its flexibility of scope and approach. It has little or no application to non-substantive questions, e.g., of remedy, which must be decided by the law of the forum, unless the lex fori specifies, as occasionally it does, that resort is to be had to the lex contractus' rules in point. Therefore, the use of the phrase "the proper law of the restitutionary remedy" in Barings \& Co. Ltd. v Cunninghame District Council' (Barings) was mistaken. The aim of this discussion is to show why the use of the term at issue, "the proper law of the remedy", either savours of some infidelity in its application to remedies or is malapropos, if ever it can be otherwise, of the issue of relief. For there is at present far too little to be garnered from the judicial or scholarly literature upon which to conclude that the applicable remedial law can be non-forum law, and it is necessary that this "non-forum law" attribute be evident in order for characteristic proper law theory to be identifiable in these or in any other respects.

Every legal subject has its own distinct basic concepts, doctrines, and terminology. These not only facilitate the judicial resolution of cases of action that belong to the given legal subject, but have also provided tenets for more thorough examination of the legal issues which inevitably must arise.

"Lecturer in the Conflict of Laws, Buckingham Law School; member, International Bar Association International Litigation Committee. I am grateful to Mr. Nicholas Davidson, Q.C. for his comments on initial drafts. The usual disclaimer applies. To F.J.

${ }^{1}$ [1996] Times Law Reports 538. 
It is in the nature of the subject of the conflict of laws that, because the laws of more than one country are potentially applicable to disputed facts, the provisions of the appropriate legal system must be identified and applied to the merits of a dispute. So it is that the common law concept of "the proper law", to use the longaccepted terminology for the object of this exercise of identification and application, has from its inception in the early decision in Robinson $v$ Bland ${ }^{2}$ been used to resolve disputes which contain elements that are properly located outside the area of application of the forum's law.

Matters of forum jurisdiction and procedure, which broadly conceptualized must by definition include the matter of remedies, have never been resolved by reference to "the proper law". Briggs has shown, however, that an analogous notion of propriety can be used to describe the justifications for the conceptually inter-related matters of the acquisition of jurisdiction on the one hand and, on the other, of the recognition and enforcement of judgments ${ }^{3}$; and remedies must be awarded or withheld in the form of a judgment ${ }^{4}$.

It is therefore a matter of importance that the term "proper law" was deployed in the context of the particularly procedural matter of remedies in the report of the decision of the Scots Court of Session (Outer House) in Barings. The use of the term in the judgment has been much overlooked in the extensive and stimulating literature which has addressed the substantive issues ${ }^{5}$. As will be seen, this focus is

${ }^{2}$ [1558-1774] All E.R. 177.

${ }^{3}$ A. Briggs "Which Foreign Judgments Should We Recognize Today?"(1987) 36 I.C.L.Q. 240 , especially at pp. $250 \mathrm{et}$ seq. The derivation of his justifications is from principles of reciprocity as a foundation for these respective matters of forum jurisdiction on which the forum's competence depends; see also the recent Court of Appeal nuling in Baghlas Lal Fafer Factory Co. BR for Industry Ltd. v Pakistani National Shipping Company.,; Pakistani National Shipping Corporation (Phillips L.J) The Times, December 17th 1997.

${ }^{4}$ See, generally, Z. Slatev "The Effects of Judgments as Remedies" in I.R. Scott (ed.) International Perspectives on Civil Justice: Essays in Honour of Sir Jack Jacob (London: Butterworths, 1990), pp. 169-178, especially at pp. 172-175 on the res judicata aspects of judgments.

${ }^{5}$ E.g., generally, J. Bird "Choice of Law and Restitution of Benefits Conferred Under a Void Contract: Baring Bros. v Cunninghame DC" [1997] L.M.C.L.Q. 182. Her comments are taken up variously in the course of the present article. Other more generalized commentary on restitution/enrichment conflicts before Barings include $\mathrm{H}$. Gutteridge and $\mathrm{K}$. Lipstein "Conflicts of Law in Matters of Unjustifiable Enrichment" (1941) 7 C.L.J. 80, K. Zweigert and D. MüllerGindullis "Quasi-Contract", Chapter 30 of K. Lipstein (ed.) International Encyclopoedia of 


\section{PROPER LAW OF A (RESTITUTIONARY) REMEDY?}

accentuated by the basis for the litigation having been in the choice-of-law aspects of agreement-related unjust enrichment conflicts. As will presently be discussed, the determination of these aspects involved the application of the proper law of the obligation, with the added factor that the agreement concerned was void ab initio. It is the report of the decision which forms the main focus of this paper.

In its characteristic form, the concept of the proper law is relevant, according to the courts, in relation to contract conflicts, and is typically expressed in terms of an objective ascertainment of the law which, by the express choice of the parties or by implication from all the circumstances of the contract, is to govern the issues arising from the contract. ${ }^{6}$ The contract, or a particular aspect of it, is then taken to be "most significantly connected or related" to one particular jurisdiction rather than to another.

Where this approach applies, its conclusive attractions - over and above, for example, the definitive selection and application of the law of a party's domicile, of the law of the place of contracting or of the law of the place of performance of a contract - have been embraced outside the common law world, notably by the States signatory to the Rome Convention on the Law Applicable to Contractual Obligations 1980 (hereafter, the Rome Convention). Subject to some modifications ${ }^{7}$, the Convention is now incorporated into United Kingdom law via the Contracts (Applicable Law) Act 1990 (the 1990 Act).

Furthermore, the doctrine has been the subject of considerable scholarly literature, e.g., as to its enduring character ${ }^{8}$, or as to its severability (or the feasibility of referring particular contractual issues to different laws if the circumstances so

Comparative Law (Tübingen: Paul Siebeck, 1974). Others, which are more recent, appear in the course of the discussion.

${ }^{6}$ The body of illustrative case law is enormous and need not be cited. For a sufficient exposition, see the House of Lords' decision in Dimskal Shipping Co SA v International Transport Workers Federation [1992] 2 A.C. 152. For a codified version, see, e.g., the Rome Convention on the Law Applicable to Contractual Obligations 1980 (art. 4(1) thereof).

${ }^{7}$ One of these is contained in s. 2(2) of the U.K. Contracts (Applicable Law) Act 1990, infra, to the effect that art. 10(1)(e) of the Convention, which provides that the proper law of the contract applies to "the consequences of nullity of the contract", is without the force of law in the U.K.

${ }^{8}$ Pace F.A. Mann "The Proper Law of the Contract- An Obituary" (1991) 107 L.Q.R. 


\title{
THE DENNING LAW JOURNAL
}

require $)^{9}$; indeed as to the indebtedness of the progress of English, general, and comparative private international law to the doctrine ${ }^{10}$. Its endearing feature, its flexibility, is at once the justification for its approval as well as a basis for its possible misapprehension, as was occasioned in Barings.

There have been various attempts to extend the scope of applicability of the doctrine beyond contract. Some fifty years ago, the late J.H.C. Morris persuasively argued in favour of the conceptual potential of the doctrine in tort conflicts situations ${ }^{11}$. These were given a substantially positive airing in United States' courts in, for example, the celebrated road traffic accident case of Babcock $\mathrm{v}$ Jackson, where

\begin{abstract}
"it [was] New York, the place where the parties resided, where their guest-host relationship arose and where the trip began and was to end, rather than Ontario, the place of the fortuitous occurrence of the accident, which [had] the dominant contacts and the superior claim for application of its law."12
\end{abstract}

English courts have, however, not accepted the concept of a proper law of a tort. Indeed, the scope of the contractual proper law hardly extends to tort issues arising in concurrent liability cases (i.e., where a tort coincides with a breach of contract, with the further incidence of liability limitation) as was maintained, for example, by the Patron of this Journal in Sayers v International Drilling ${ }^{13}$. At the Court of

${ }^{9}$ C.A. McLachlan "Splitting the Proper Law in the Conflict of Laws" (1990) Vol. LXI B.Y.B.I.L. 311 .

${ }^{10}$ E.g. , F.A. Mann "The Proper Law in the Conflict of Laws" (1987) 36 L.Q.R. 437. R. Fentiman's is a lone voice that usefully applies the term to matrimony: "The Validity of Marriage and the Proper Law" (1985) 44 C.L.J. 256, at pp. 257 et seq.

11 “The Proper Law of a Tort" (1951) 64 Harv. L.Rev. 881; see also(1946) 62 L.Q.R. 180.

12191 N.E. 279 (1963), per Fuld J.; see also Kilberg v Northern Airlines Inc. 9 N.Y. (2d) 34 (1961). A valuable discussion of the broader jurisdictional framework is provided by Kurt Siehr's "Traffic Accidents" in C. McLachlan and Hon. Peter Nygh (edd.) Transnational Tort Litigation: The Jurisdictional Principles (Oxford: Clarendon, 1996), at p. 192.

${ }^{13}$ [1971] 3 All E.R; see also L. Collins Essays in International Litigation and the Conflict of Laws (Oxford: Clarendon Press, 1994), Chapters IX ("Interaction between Contract and Tort in the Conflict of Laws") and X ("Exemption Causes, Employment Contracts and the Conflict of Laws"), especially between pp. 397-402 where he discusses Sayers. 


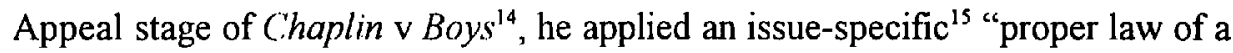
tort", only to be over-ruled on appeal to the House of Lords ${ }^{16}$.

A liberal reading of the leading speech delivered by Lord Slynn, in the much more recent case of Red Sea Insurance Ltd. v Bouygues $S A,{ }^{17}$ could perhaps be seen to contain a modest degree of acceptance of an attenuated issue-specific version of the doctrine, as it might apply to international torts, particularly where his Lordship stated that

"the exception [to the application of English law] is not limited to specific isolated issues but may apply to the whole claim, for example, where all or virtually all of the significant factors are in favour of the lex loci delicti."18

Previously in the same judgment ${ }^{19}$, he roundly rejected the theory of a proper law of a tort, but admitted a policy of flexibility in identifying the applicable substantive law. On the issue of relief, one might be inclined to presume that were the lex loci delicti to contain remedial rules, then such rules would be directly applicable unless some other reason (e.g., public policy; incompatibility of the forum and the lex delicti forms of relief) dictates otherwise.

A further instance of the type of objectivism associable with proper law theory is to be found in s.11(2)(c) of the Private International Law (Miscellaneous Provisions) Act 1995 (the 1995 Act) which provides that in multi-locality torts, the applicable law is the law of the country in which the most significant element or elements of the events constituting the tort or delict in question occurred.

Whatever be the conceptual potential of such practical extensions of proper law theory and method, it is to be noted that there is neither express judicial authority for the doctrine in relation to matters other than those arising ex contractu. Nor are

${ }^{14}$ [1968] 2 Q.B. 1.

15 That is, as may be contrasted with one that is broadly specified by the cause-of-action itself.

${ }^{16}$ [1971] A.C. 356 , at pp. 389 and 391

${ }^{17}$ [1995] 1 A.C. 190.

${ }^{18}$ ibid., at pp. 207-208.

${ }^{19}$ ibid, at p. 206. 
there sufficiently compelling indicators that the typification of the doctrine - as has thus far in the literature been confined to substantive contractual issues characteristically also covers issues of jurisdiction or those of procedure, such as the all-important matter of relief. Of itself, judicial relief is arguably the ultimate test of the efficacy of the judicial process.

It is the particular circumstances of the Barings case in point which must now be attended to. It is just as well to add that the forthcoming enquiry aims to point out the error or, at best, the inchoacy in the unlikely use to which the term was put. A sound viable alternative will be described, to give as much rein as the present medium will allow to the plurality of considerations that must attend the use of the term.

The remainder of the paper is sectioned as follows: a discussion of the facts and contentions in Barings; the issues from "proper law", and "remedy"; the decision, and its consequences and implications; applicable remedial law: objective localization; and finally a conclusion.

\section{BARINGS: THE FACTS, AND THE CONTENTIONS.}

Barings is one of many case ${ }^{20}$ arising from agreements between a number of local authorities acting ultra vires on the one hand and several banks on the other ${ }^{21}$. The pursuers were a bank who with the defenders had made a forward-rate swap agreement, defined in Barclays Bank plc v Glasgow City Council as

"an agreement ber veen two parties whereby one pays to the other, over

${ }^{20}$ Other similar fact cases include Barclays Bank plc v Glasgow City Council; Kleimwort Benson Ltd v Glasgow City Council [1994] 4 All E.R. 864; Westdeutsche Landesbank Girozentrale v Islington London Borough Council [1994] 4 All E.R. 890; Kleimwort Benson Ltd v Sandwell Borough Council; Kleimwort Benson Ltd v South Tyneside Metropolitan Borough Council [1994] 4 All E.R. 972; Morgan Guaranty Trust Co v Lothian Regional Council 1995 SLT 299 (in which the earlier parallel English case of Hazell $\vee$ Hammersmith and Fulham Borough Council [1990] 2 Q.B. 697 is examined); Macmillan Inc v Bishopsgate Investment Trust plc (No 3) [1996] 1 All E.R. 585.

${ }^{21}$ That is, with the exception of the Court of Appeal decision in Macmillan in which the parties were a communications company and an investment company, and the subject matter was confined by the court to whether the lex situs governs issues of priority to ownership of shares in the wider but unresolved framework of restitution conflicts: cf. J. Stevens "Restitution or Property? Priority and Title to Shares in the Conflict of Laws" (1996) 59 M.L.R. 741, and A. Dickinson "Restitution and the Conflict of Laws" [1996] L.M.C.L.Q. 556. 


\section{PROPER LAW OF A (RESTITUTIONARY) REMEDY?}

a period of months or years, sums calculated by reference to the difference between a fixed rate of interest and the current market rate of interest from time to time...The contract does not involve a loan...The essential feature of the contract is that it is a futures contract, the financial outcome of which depends on future movements in interest rates. The transaction could be used as a genuine hedge transaction, or it could be used for speculation"22.

The British Bankers Association standard form developed specifically for these agreements was used. The form had provided for English law as the governing law. In furtherance of the supposed contract, the defenders had paid monies to the pursuers, on which basis the latter subsequently paid back larger sums believed by the parties, at the time, to be contractually due. The contract itself was subsequently agreed upon between them as being void ab initio, following the decision in Morgan Guaranty Trust Company v Lothian Regional Council ${ }^{23}$ (hereafter, Morgan) on identical facts, because the defender local authority lacked the necessary contractual capacity.

The House of Lords had first held such contracts void in England in Hazell v Hammersmith and Fulham Borough (ouncil ${ }^{24}$ and, from the perspective of practical advice, it may be questioned why a Scottish local authority had agreed to subject the vires aspects of its activities to rules other than those of its parent legal system, but this was of course not an issue in the case.

The pursuers in the case in hand had asserted English law, the supposed governing law of the agreement, as the only legal system which allowed a restitutionary remedy: a policy-based assertion, that the legally regulated obligation ought to be legally remediable. The pursuers' presumption was that English law would allow the (Scots) restitutionary remedy of payment. English law does not literally so permit, although the remedial process might conceivably provide identical results under either legal system.

They had derived their entitlement to restitutionary relief from the restitutionary right to recover the excess by which the defenders were unjustly enriched. By Scots law, the forum law of the defenders' domicile, the claim was extinguished by

\footnotetext{
${ }^{22}$ Supra note 20, at pp. 882-883, per Lloyd L.J.

${ }^{23}$ Supra, note 20 .

${ }^{24}$ ibid.
} 
prescription $^{25}$.

That they had sued in Scotland (the defenders' domicile), rather than in England (the jurisdiction of the parties' supposed choice of governing law), was ostensibly well within the defendant-protecting policy of the applicable jurisdictional rule contained in article 2 of the Brussels Convention on Jurisdiction and Judgments in Civil and Commercial Matters 1968 (Brussels Convention), as it is incorporated into United Kingdom law in Schedule 4 of the Civil Jurisdiction and Judgments Act 1982 ( the $1982 \mathrm{Act}$ ). The question of the right forum turns up in the course of the paper ${ }^{26}$, and can be said to strengthen the basis for consideration of procedural matters of forum jurisdiction and judgment in identical terms, differently from those of the substance or merits of the obligation; to reiterate, the latter are the typical subject of proper law theory.

The defenders argued that in accordance with Morgan, both under the contract and under English law, the proper law of the contract, there was no claim to restitution. This argument is difficult to accept since there was, without doubt, an unjust enrichment, even though the claim was difficult to formulate.

The main questions arising concerned, first, the extent to which the issues and ratio in Morgan - a case pleaded, argued and decided as a domestic case although there was a choice-of-law clause in favour of English law - could apply to the instant conflicts case. This issue was disposed of by distinguishing the cases further on the point that the wholly domestic Scots circumstances and, consequently, the test applied in the former did not divulge the best method to be deployed in the latter case in identifying the legal system with which the quasi-contractual obligational situation was most closely related.

The second and more interesting question, as was expressed by the Court, was whether the proper law which validated a contract also determined the nature and extent of the available restitutionary remedy. It is to be noted that, in the present case, the contract itself was itself incapable of validation howsoever (not even by the parties' supposed choice of law) since it was void. The reason for Scottish suit ${ }^{27}$ may be recalled, but it need not be reviewed at this stage of the present paper.

${ }^{25}$ Cf. s. 6 Prescription and Limitation (Scotland) Act 1973.

${ }^{26}$ In the main text, after n. 54.

${ }^{27}$ I.e., furtherance of art. 2 Brussels Convention stupra. 


\section{THE ISSUES: "PROPER LAW", "REMEDY".}

The ratio in the decision of Lord Penrose, allowing a proof before hearing ${ }^{28}$ in the action, was that the law of the remedy sought (of payment) was not necessarily also the supposed contractual lex causae. The result, by which Scots law applied, was consistent with his judgment in Morgan. His Lordship proceeded to entertain proof of the relevant provisions of the law of the physical locus (England) with which the contract was materially connected, and which might or might not have been the proper law of the (void) agreement. The result reached (technically, his answer) was that the proper law did not, qua validating law, necessarily apply to the availability of the given remedy. This finding is neither difficult to grasp nor, by analogy, different from the conceptual separation between the enrichment which underpins the cause of action for restitution on the one hand (governed by the lex causae) and an award of restitution itself on the other (a matter for the lex fori).

However, much more significant and inviting considerations for the ripening law of enrichment conflicts ${ }^{29}$ are raised, mostly because of the frequent, and even casual, references to considerations of propriety of the typically procedural matter of remed $y^{30}$. His Lordship rightly observed that these and related questions had been "the subject of debate among eminent jurists and other commentators, but had received little attention from the courts", that "there was no binding authority and that there was a lack of convincing analysis in such authority as existed on the critical issues in the case ${ }^{131}$. He opted for a flexible approach ${ }^{32}$ which was redolent of Lord Wilberforce's authoritative predilection for flexibility (as to the different matter of the lex delicti for international tort actions) in Boys v Chaplin in the House

${ }^{28}$ This procedure is provided for in s. 72 Court of Session Act 1868, to enable the establishment of the facts in issue before trial on the merits.

${ }^{29} \mathrm{Cf}$. the decisions in note 20 , supra; also, A. Briggs "Restitution Meets the Conflict of Laws (Macmillan v Bishopsgate)"[1995] R.L.R. 94; J. Bird "Restitution's Uncertain ProgressMacmillan v Bishopsgate" [1995] L.M.C.L.Q. 308; and generally, F.D. Rose (ed.) Restitution and the Conflict of Laws (Oxford: Mansfield Press, 1995).

${ }^{30}$ Cf. L. Collins et al (edd.) Dicey and Morris on the Conflict of Laws (London: Sweet \& Maxwell, 12th ed., 1993), pp. 171-172, on remedies as procedure, consequently, for forum internal law.

${ }^{31}$ At p. 13 of the transcript.

${ }^{32}$ At p. 16 of the transcript. 


\title{
THE DENNING LAW JOURNAL
}

of Lords ${ }^{33}$, as well as of Blaikie ${ }^{34}$. The same flexibility may, in more general terms, be identified in sections 6 and 221 of the American Law Institute's Restatement Second of the Conflict of Laws ${ }^{35}$.

Of itself, his Lordship's decisive preference for flexibility may well have substantially explained the use of the term "the proper law of the restitutionary remedy", not least because he did not himself consider the non-enrichment ramifications of his preference, nor was he required by counsel to have done so. In the first place, it is neither unusual nor necessarily incorrect to associate "claim" or "action" with "remedy", without referring to the discrete formal aspects of "remedy". It has been incidentally observed that

\begin{abstract}
"[t]he reality is that restitution actions which arise out of void contracts are, in a sense, merely contractual remedies and the law which declares the contract to be void is the most suitable to regulate the consequences of that finding $\mathrm{g}^{36}$."
\end{abstract}

Furthermore, the on-going unpacking of the law of restitution in the conflict of laws is pervaded by the choice of law aspects thereof, and this is so, predominantly, because of the important divergences of approach between different restitutional systems to which a given fact-situation could conceivably be related ${ }^{37}$. This would make flexibility of approach, in general terms, particularly attractive in these circumstances. All the same, an "action" is for a "remedy" (as in an action for

${ }^{33}$ Supra, note 16.

${ }^{34} \mathrm{~J}$. Blaikie "Unjust Enrichment in the Conflict of Laws" [1984] J.R. 112.

${ }^{35}$ (St. Paul, Minnesota: A.L.I. Publishers, 1971).

${ }^{36}$ Bird, loc. cit., at p. 186 (emphasis added). Thus, "action" and "remedy" (the latter construed in its weaker sense to be synonymous with the former) both go to the redress of the deleterious effects of a contract or other obligational situation; see the present writer's "Forum Discretion in Assuming Jurisdiction under the Brussels Convention: Pearce v Ove Arup Partnership and Others and the Rôle of the Doctrine of Forum Non Conveniens" (1997) 9 A.J.I.C.L. 673, at pp. 675-676 (paras. (5)-(7) there; see also K. Barker "Rescuing Remedialism in Unjust Enrichment Law: Why Remedies are Right" (1998) 57 C.L.J. 301, especially at pp. 304306, 318-326.

${ }^{37}$ Cf. B. Dickson "Unjust Enrichment Claims: A Comparative Overview" (1995) 54 C.L.J. 100: that in comparativist terms, the law of restitution has disparate origins, applications and policies, in the jurisdictions in which it is to be found. 


\section{PROPER LAW OF A (RESTITUTIONARY) REMEDY?}

restitution or, better, an action of unjust enrichment), and the remedy can be analyzed of itself without necessarily requiring its being related to the particular underlying cause of action which in its turn may deserve separate attention.

McGregor's reasoned inclination ${ }^{38}$, albeit in the rather different setting of refuting the separate term "restitutionary damages", for separately addressing the concepts of "unjust enrichment" and of "restitution" must be instructive in present respects in that it rightly emphasizes the remedy itself.

Granted that the use of the term "the proper law of a restitutionary remedy" may simply have been a misnomer for the law applicable to the substance of the enrichment, ampler discussion is nonetheless necessary because of the sheer but unacknowledged novelty (with a host of implications) of the use of the term. For instance, the use of this term might signify that the various problems associated with remedies, although usually treated as a matter of procedure in the conflict of laws, and, thus, traditionally governed by the lex fori, could be analysed in greater detail to determine whether one or other aspect could be governed the law of another state.

Herein lies the difference between conceptualizing remedies in the conflict of laws and developing "a proper law of the remedy"; either may be said to go to the applicable remedial law. The former is the present writer's preference.

The forum-oriented consequentialism of the decision ${ }^{39}$, thus the long-standing association of remedies with forum $\operatorname{law}^{40}$, makes it the ideal medium for the discussion that now follows, beginning with the responsive intersection between "substance" and "remedy". The added consideration is that the circumstances are balanced between Scotland and England, and these respective legal systems did have significantly well-founded claims to being applicable to the dispute - a real conflicts case.

\section{THE DECISION, AND ITS CONSEQUENCES AND IMPLICATIONS.}

(i) The restitutionary right to recover.

The decision was based on the differentiation of the issue of the (enforceable)

${ }^{38}$ In "Restitutionary Damages" in P.B.H. Birks (ed.) Wrongs and Remedies in the TwentyFirst Century (Oxford: Clarendon, 1996), p. 203, at p. 204.

${ }^{39}$ See, e.g.,Bird, loc. cit., pp. 191 (in the text there preceding its note 67) and 192 (her main text before note 69).

${ }^{40}$ Cf. Dicey and Morris, Rule 17, op. cit., p. 169. 
restitutionary right to recover from the issue of the enrichment so that, as incidentally was argued by the defenders, the respective concepts could in a suitable case conveniently be governed by different legal systems: for example, the former by the normal forum law for the particular (restitutionary) remedy sought, and the latter by the law that governs the substance of the enrichment (the lex causae). This would be in accordance with normal conflicts methodology by which co-ordinated remediability by forum and substantive laws is the fixed rule, as was applied for example in Phrantzes $\vee$ Argent $^{41}$, where the lex causae obligation to provide dower was unenforceable because the available forum law machinery was inapposite to the upholding of that obligation.

It needs to be made clear that it is in the nature of the conflict of laws that the ascertainment of an entitlement in accordance with a non-forum lex causae does not automatically convert the entitlement in question into one which the forum can or will enforce through its own machinery. Therefore, such an entitlement only becomes enforceable, qua "right", in the eyes of the forum where the procedure exists to affirm the status of the entitlement as a full-fledged right.

Thus, if "established legal right to recover" and "form of legal recovery" are to be considered conjunctively (strictly speaking, they are differentiable) on the basis that they may have been established by reference to the same law, then there can be little analytical or practical difficulty. As was the case in the Barings decision, these precepts need respectively to be conceptualized and subjected to the correct law(s). Put differently, there being a forum action/remedy upon which to prosecute a claim (on the one hand) for a proven unjust enrichment (on the other) are best considered disjunctively. To describe these otherwise would misconceive them as being one and the same issue, which they invariably are in a purely domestic case (e.g., Morgan), whilst in a conflicts adjudication they might well be separated out.

If by definition either issue were exclusively governed by the lex causae, especially where the underlying contract is void, then the result, as given in the report, would be to produce

"a fundamental difficulty to be overcome in seeking within what was $e x$ hypothesi a nullity the solution to the choice of law aspects of the problem of restitution. The proper law had exhausted its purpose in dictating that solution and it was not attractive to proceed then to give effect to a term of that contract when the contract had ceased to have any validity between

${ }^{41}$ [1960] 2 Q.B. 19, at p. 35. 


\section{PROPER LAW OF A (RESTITUTIONARY) REMEDY?}

the parties" ${ }^{32}$.

In this way, his Lordship discountenanced the application of the parties' English choice-of-law clause.

(ii) "Substantial" logic and justice: remedies and the choice-of-law process.

To have disapplied that choice, as Lord Penrose did, was to serve the ends of "substantial" logic and justice 43 . This did not mean, as his Lordship recognized in allowing for any fortuity as to the identification of the locus of the enriched party and of the enrichment itself $f^{44}$, that the parties' supposed but judicially avoided and overruled choice of substantive law could not ultimately be "relevant and material"45 to the issues of restitution, "but will not per se be determinative of that connection" $" 46$; or, indeed, by civil analogy, that substantive law may generally be relevant and material to other relief in a different cause of action.

The judgment also stated

"that (a) the restitutionary obligation [not the restitutionary remedy] or quasi-contractual obligation is govemed by the proper law of that obligation; and (b) that the proper law of the obligation is the law of the country with which, in light of the whole facts and circumstances, the critical events have their closest and most real connection" ${ }^{147}$.

${ }^{42}$ ibid., at p. 13 of the transcript.

${ }^{43}$ Ibid, at pp. 13-14 of the transcript.

${ }^{44}$ ibid.

${ }^{45}$ ibid.

${ }^{46}$ ibid., p. 16; see also McLachlan and Nygh (edd.), op. cit., pp. 230-231 (albeit in relation to tort-generated enrichment): "It has the merit of focusing on the enrichment itself - perhaps the best common guide to decision in this complex area of the law", having considered the justness and the convenience of the law of the locus of the assets (or, as in the present case, the money) involved, the law of the place where the obligational situation is centred; see also Chase Manhattan NA v Israel-British Bank (London) Ltd. [1981] Ch. 105, in which the law of the place of enrichment was applied.

${ }^{47}$ At p. 16 of the transcript, citing Blaikie; cf. Dicey and Morris' Rule 201, pp. 1471-1478, especially p. 1473 (page 10 of the transcript); also, Arab Monetary Fund v Hashim [1996] 1 
This means that the substantive restitutionary obligation involves likewise the choice of law, but not that the award of a given (procedural) restitutionary remedy likewise categorically involves the choice of law. The reason for this is that the available remedy need not be the one which is indicated by the law by which the unjustness of the enrichment will have been established.

Before the matter of remedial law itself is taken up in the next section, some light needs briefly be shed on a number of significant practical issues arising from the foregoing analysis, in particular, on the matter of the "substantial logic" upon which the application of Scots law was founded. First, it would appear to have been sound advice if the parties had in fact made provision for agreed remedies partly to remove issues from practical policy, for example, the question whether the legal entity neither constituted, domiciled, and managed in nor subject to the relevant foreign substantive law did in fact wish to be subject to that non-forum law, especially where the issue is the validity and consequence of its transactions. It also seems fair to examine that law and to seek to bring it to bear on the considerations. Or, finally, the parties could have agreed that an English forum exclusively should have jurisdiction over matters arising under the agreement.

(iii) Bird's commentary on Barings.

The view that choice-of-law method could be applied to the more strictly remedial aspects of conflicts cases in general is not new. It is perennially relied upon by counsel, as for example in Baschet's Case where French law of injunction was the basis on which argument in an action for that remedy from an English forum was founded ${ }^{48}$. From the (procedural) standpoint of remedies, this view tends to (over)emphasize the scope of relevance of the underlying substantive aspects of a breach of obligation. The resolution of these aspects themselves is properly subject to choice-of-law, and in relation to the restitution-based facts at present under consideration, this subjection has been most commendably examined by $\mathrm{Bird}^{49}$.

The gist of her rigorous and compelling analysis runs against the actual decision in Barings. She argued that the application of the supposed proper law of a void

L1.Rep. 589, at p. 597: "The obligation to restore an enrichment obtained at another's expense is governed by the proper law of the obligation."

${ }^{48}[1900] 1$ Ch. 73 .

${ }^{49}$ loc. cit., stpra, note 5 . 


\section{PROPER LAW OF A (RESTITUTIONARY) REMEDY?}

contract, qua lex causae of an action for restitution, is in fact neither illogical nor unjust $^{50}$; because (a) the void contract is nonetheless "a reference to something which the parties have actually done and is intimately connected to the restitution claim before the court"s1, (b) "the void contract contains evidence of the most appropriate law to govern the restitutionary claim"s2 (c) it "is...in conformity with the parties' expectations" and is of the parties' choosing or is "the law of the country with which the contract is most closely connected"s3, and (d) is likely to be the law which is most closely connected to the restitutionary claim consequent on that failure and which has the "greatest interest in regulation of that claim"s5, thus suggesting to this writer that the claim ought reasonably to have been brought in England, and (e) "from a practical perspective, the two issues [of what avoids a contract and whether payments made under a void contract can be recovered] are intimately related; very few of the legal problems encountered by those lawyers are likely to raise the latter but not the former issue. Accordingly, it is difficult to see why the two issues should be governed by different laws 255 .

She made clear that, for her, "[w]hile from the point of view of strict legal theory the question of whether a contract is void falls under a different category to the question of what the consequences of that finding are, from all other points of view it is the same question." 56 But contractual validity, and its effects, are really not at

${ }^{50}$ At least not where the contract is correctly nullified for other types of reason, e.g. fundamental mistake, misrepresentation, or duress. The parties cannot have been ad idem in any of these situations.

s1 loc. cit., p. 184.

\$2 ibid., at p. 185.

${ }^{53}$ ibid, see also art. 4(1) Rome Convention.

${ }^{54}$ ibid., p. 186. As was pointed out, supra, at note 8, the 1990 Act excludes art. 10(1)(e) of the Rome Convention, which article provides to refer the consequences of nullity to the proper law of the contract. In relation to restitution claims based on a void contract, at page 14 of the transcript, Lord Penrose felt constrained to have explained this reservation in terms of a legislative intention to separate the lex causae as to nullity from the lex causae as to the contract. Hansard ((1989) 513 HL Debates, Cols. 1257-1273) makes clear that the (legislative) Lords reckoned with a distinction between unjust enrichment and contract, but not that the reservation was specifically aimed at unjust enrichment and any restitution (better, restitutionary orders) consequent thereon.

\footnotetext{
ss ibid., p. 186.

${ }^{56}$ ibid.
} 
all the same question from the practical remedial point of view of the form of relief that may apply to an enrichment consequent to nullification.

It is nonetheless deserving of attention that she took issue with the decision to disapply the putative proper law in favour of a forum-oriented approach. Nor is her view, that the declined law (albeit, not qua parties' choice) ought to be a voidcontracts' exception to Lord Penrose's flexible rule ${ }^{57}$, without considerable foundation in commonsense, judicial convenience and, thus, in doing justice as between the parties. She had later concluded ${ }^{58}$, however liberally, that in the final analysis it is but a fine line between his Lordship's view and hers, and that it is the issue of optimizing flexibility in the individual case that separates the respective views. With respect, the differences of rationalization and practice can be quite substantial and, having regard to the differences between his Lordship's and her views, flexibility is therefore deceptively variable. Indeed, closer to the present obligational situation, similar argument was extensively relied on in the Arab Monetary Fund cases $^{\text {s9. }}$.

That the contract is void in the present case is, for the sake of argument, sufficiently easy to prevail over ${ }^{60}$ so as to permit, for example, the substitution of the question of the effect of the void contract as between the parties (or their restitutionary liability) with the effect of the parties' voluntary and legally imposed relationship (their liabilities from the agreement).

(iv) A feasible via media: re-emphasizing forms.

The present writer's view is, in several respects, a via media in its relation to the judgment which correctly, it is submitted, conflates remedial law with a flexible forum-oriented approach on the one hand, and in its relation to Bird's no less flexible but different view, on the other hand, that the legal obligation and its governing law are often really quite inseparable and that less is to be made of systems' differentiation as to remedies and remedial law.

As presently will be argued, flexibility, as to obligation and to relief, is an appealing proposition in theory as well as in practice since it reconciles these

${ }^{57}$ Supra, page 99.

${ }^{58}$ At p. 192.

${ }^{59}$ Arab Monetary Fund v Hashim; Arab Monetary Fund v Bahiralullom (29th July 1994; CH 1988 A No. 9317; unreported; Chadwick J.).

${ }^{60}$ Cf. Bird, loc. cit., p. 186. 
otherwise divergent perspectives. It differs from his Lordship's position in that the respective issues should be governed in the present case by the same law but not on the same bases. It is important not to disregard the matter of form which is unavoidable.

Pared of his Lordship's adjudgment in response to the parties' arguments as to applicable law, the decision itself could be described as the result of the application of forum law to all the issues of obligation and relief, on the bases that forum substantive law was applicable in default of English law.

It differs from Bird's in that the degree of flexibility which she advocates would leave the theoretical underpinnings (the conceptual legal differentiation of "obligation", "remedy", and "proper law") substantially underplayed and at some cost to both theory and practice: the result of her view would be that English law directly applied to establish an obligation to disgorge, to which the forum would presumably then respond by converting the obligation into an enforceable forum right. She stopped short of the issue of forum remedy, either in the sense of forum action or of forum remedial order.

Although the forms of action themselves were abolished in the Common Law Procedure Act 1852 (and with this came a cause-based re-classification), it must be remembered that "the forms of action were not legal remedies", and "were specific situations of fact which acted as models or templates for deciding whether or not a litigation dispute could get into the Royal courts ${ }^{62}$."

The action could arguably have been brought in the English courts as the law of the place of characteristic performance of the agreement, mindful that article 5(1) in Schedule 4 (the Brussels Convention as it applies within United Kingdom jurisdictions) of the 1982 Act could permit exception to article 2, the latter article otherwise favouring the courts of the defenders' domicile.

In the decision of the House of Lords in Kleinwort Benson Ltd. v Glasgow City Council $^{63}$, with much the same facts, the action was brought in England for the English restitutionary remedy of recovery of money paid. In Kleinwort Benson, the separate characterization of restitution claims, from contract-related claims arising under the Brussels Convention, was upheld. The effect was to disconnect the type of claim involved in these cases from contract claims so that article 5(1) was neither

${ }^{61} \mathrm{G}$. Samuel "Classification of obligations and the impact of constructivist epistemologies" (1997) 17 Leg. Stud. 448, p. 461.

${ }^{62}$ ibid.

${ }^{63}$ [1997] 3 W.L.R. 923. 
necessarily relevant not applicable, and article 2 prevailed.

It ought perhaps to be reiterated that what is novel in Barings, and thus of substantial interest, is the report's usage of the term "the proper law of the remedy" as though it is accepted legal parlance. The unprecedented inference is that proper law method, e.g. as espoused by F.A. Mann ${ }^{64}$, need not be limited to solving questions of substantive obligation ${ }^{65}$, that it extends to matters of remedy. Nor were the full practical, as well as the theoretical, consequences of deploying the phrase "proper law of restitutionary remedy" as such considered in the present case. As far as the present writer is aware it has not been used at all elsewhere ${ }^{66}$.

(v) Reviewing the problem from differentiation.

The problem then becomes this: if the forum of adjudication, therefore the nature and extent of the available remedy, is to be Scottish (as it was in Barings), the prospect exists that the pursuers will unjustifiably go without relief if, as Bird appears to suggest, the nature and extent of relief were to be referred to the same law as would govern and settle the issue of obligation to provide relief (in the sense of an obligation to disgorge). The supposed English law did not, in the eyes of the Scots forum, automatically apply so as to give that relief or as would found a restitutionary obligation which the forum was able to enforce. This result would be no less unjust, for different reasons, than an outcome based on rigidly separating substance from remedy. To do so would sallow the merits of deliberating their intersection.

What the report presents then is a problem from terminology analogous to the dilemma which, several decades ago, was encountered with regard to damages, wherein the measure of damage (heads of recoverable damage) was erroneously equated with the measure of damages (or quantum), e.g., by McNair J in NV Handel

${ }^{64}$ loc. cit., supra, at note 10.

${ }^{65}$ See the House of Lords' decision in Dimskal Shipping Co SA v International Transport Workers Federation, supra note 6 , on the point that a restitutionary obligation arising ex contractu is governed by the proper law of the contract. If the obligation is non-contractual, the law of the place of enrichment applies.

${ }^{66}$ Surprisingly, and likely for reasons of the timing of the Report, Dickinson, loc. cit. supra at note 21 , banishes discussion of the instant case to the final footnote of his very informative paper, and even there he does not engage in the point at issue in this comment. 


\section{PROPER LAW OF A (RESTITUTIONARY) REMEDY?}

Maatschaapij J Smits Import-Export v English Exporters ${ }^{67}$, or by Lord Upjohn in Boys v Chaplin ${ }^{68}$. In the case of damages, the problem, with its analytical consequences for conflict of laws' remedial adjudication, was since removed with the abandonment all together of the former expression.

Their Lordships' conflation, if that indeed is what they respectively did, of the substantive right to damages with the remedial, or procedural, amount of damages is otherwise acceptable in that the conflation would involve the application of the same law where appropriate whatever be the formal description of that law, substantive or procedural ${ }^{69}$.

(vi) The convenience of the forum of adjudication.

The forum could apply the rules of quantum from another legal system, even though such rules are clearly procedural, as is required for example in article $10(1)(c)$ of the Rome Convention.

As Kramer noted, outwith the scope of the same convention, "[a] choice of law problem exists only if the different laws relied on by the parties can plausibly be construed to govern the case, ${ }^{, 70}$ and, more extensively, that ${ }^{71}$ :

"One might...object that this imposes a substantial burden on forum courts to learn and apply foreign rules of procedure, an objection reminiscent of the justification for the traditional approach [of applying only forum procedural rules]. But the court need learn only foreign procedural rules that serve substantive [res judicata] purposes... Moreover, the adversarial system naturally limits this burden, since the court will consider only foreign rules that are properly raised by the parties. Finally, finding and applying foreign procedural rules is no more difficult than finding and applying foreign substantive law...Indeed, the premise of this canon is that

${ }^{67}[1955] 2$ LI. Rep 69, at p. 72.

${ }^{68}[1968] 2$ Q.B. 1, at p. 31.

${ }^{69}$ See, e.g., the present writer's " $A$ Critique of the Orthodoxy of Excluding Foreign Law in the Evaluation of Compensatory Damages in the English Conflict of Laws: Considerations of Propriety of Quantum" (1986).

70 "Rethinking Choice of Law" (1990) 90 Colum. L.Rev. 277, at p. 283.

${ }^{71}$ ibid., pp. 328-329. 


\section{THE DENNING LAW JOURNAL}

some foreign procedural rules should be applied because they are in reality part of another state's substantive law."

Illuminating and, with respect, correct as the foregoing passage is, it does not affirm the accuracy of the particular term which provides the topic of the present commentary. This is because the undifferentiated procedural rules to which he generally refers do not necessarily have within their particular purview the formal aspects of the actual forum remedies (in the present case, restitutionary) ${ }^{72}$.The passage does, however, accentuate the decisive judicial policy of the practical convenience ${ }^{3}$ with which non-forum rules at issue (in present terms, remedial) may be applied, be they characterised as procedural or as substantive.

(vii) Barings, remedies and "the centre of gravity" generally.

If a given cause of action lies not in contract but, for example, in tort - as would require reference to the lex causaellex delicti (or however else it is more particularly to be described ${ }^{74}$ ) rather than to proper law considerations in their true meaning - it nevertheless would not be amiss to enquire as to whether the particular facts centre upon a particular legal system, in seeking to correlate the finding as to remedial liability with the finding as to how and how far it is more formally to be redressed.

Indeed, where the relief is not in money, the metaphorical plot must thicken. That it was restitutional liability in Barings can, hypothetically speaking, be regarded as random enough ${ }^{75}$ to afford an adequate basis for obligational and remedial analogues. Indeed if the facts had been different, such as if they had included a positive genuine affirmation of the pursuers' as to their contractual capacity, a tort action based on negligent misrepresentation would have produced factually different

72 In a forthcoming book, Judicial Remedies in the Conflict of Laws (in Chapter Six thereof), the present writer makes the pragmatically justified case, having limited application, for conflicts remedies which will comply (as they must) with the formal attributes of the same remedies in domestic cases but which by reason of the cross-border circumstances of the cases in which their consideration will arise, need not be rationalized in precisely the same way as their domestic case counterparts.

${ }^{73}$ Dicey and Morris, pp. 169 et seq. generally discusses this issue as it underpins procedure.

${ }^{74} \mathrm{Cf}$. the introduction (Background considerations) to this article.

${ }^{75} \mathrm{Cf}$. text bearing $\mathrm{nn} .41$ and 42, supra. 


\section{PROPER LAW OF A (RESTITUTIONARY) REMEDY?}

but thematically related factors.

For the present discussion, the main advantage of the true facts in Barings is that they gravitated towards a legal system which is not also the legal system of the forum. The point which is thereby brought home is that there is much to be said for the fact, as expressed by Trooboff in relation to tort claims based on intellectual property rights, that "courts have been asked to moderate the effect of the limitations on their jurisdiction fostered by the operation of local-action or territorial principle cases."76

The decision to award a restitutionary remedy (one that is available precisely because non-forum substantive law is applicable) will exclusively depend on forum law for its form but arguably not necessarily for its rationalization or its governing principles. It is the preponderance of form which then will dictate the extent to which lex causae procedural rules will be applicable by the forum. The preponderance of form is, not what justifies, Bird's identification of "the homeward trend and the result orientation"77 in Lord Penrose's reasoning. It is the form that limits the stricter restitutional rules to the subset of "procedure". And it is the preponderance of form which must definitionally settle the bounds of considerations of propriety as to these rules.

The pre-condition for this interpretation is that the remedial rules of a non-forum lex causae, if any, would need to be on all fours with those of forum substantive law in point, especially where every factor, apart from the locus of the litigation, points to the lex causae. The same rationale supplies a basis from which the issue of applicability of remedial rules derives and is to be resolved; otherwise, the issue of applicability would not arise because remedies are tacitly part of forum process which of itself is typically seen to depend mandatorily and exclusively on forum law.

The remedies issue belongs to the wider matter of jurisdiction (or process) wherein substantive entitlement must deterministically feature. And it has been settled law, since Re Bonacina ${ }^{78}$, that lex causae categories need not precisely mirror those of the forum domestic law, so that, in that case, lack of consideration in the agreement with an Italian proper law did not prevent rights thereunder being enforced by the English forum. Each remedy that makes up the forum's armoury of relief need not, or cannot, individually be expanded upon in this paper. But the

${ }^{76}$ In "Intellectual Property" in McLachlan and Nygh (edd.), op.cit., at pp. 128-129; generally, ibid., 128-132 ("Broadening the Scope of Claims Asserted and Relief Granted").

${ }^{77}$ loc. cit. e.g., at p. 192.

${ }^{78}$ [1912] 2 Ch. 394; contra Phrantzes v Argenti, at note 40, supra. 


\section{THE DENNING LAW JOURNAL}

Barings facts have been shown to be versatile enough to accommodate further broad remedial considerations and indicators.

(viii) A recapitulation.

Proper law theory and practice runs with legal relationships in which party autonomy is an over-arching consideration. It typically involves situations in which the parties' contractual freedom is recognized and enforced by the forum, wherein that autonomy is factored into the judicial redress. Autonomy does not feature in relation to forum procedure in general. Indeed, as Jolowicz pointed out, "[s]ubstantive law is, procedural law is not, 'self-executing"'? , so that autonomy ends with the parties' subjection of their legal relationship to the procedural rules of the forum.

Although party autonomy does feature in contract, its scope does not quite extend to judicial relief in formal terms but, in having resolved the lex causae/proper law of the contract, will have indicated the law the remedial (procedural) rules of which are to be considered for remedial applications. So it is that, in Penn v Lord Baltimore ${ }^{80}$ or in Richard West \& Partners (Inverness) Ltd. $\mathrm{v}$ Dick ${ }^{81}$, the English forum was able to award decrees of specific performance of contracts relating to foreign land. The respective awards complied with the leges siti in which their actual enforcement was to take place, and defendant default would have met with contempt proceedings before the awarding forum. In these cases, the defendants were forum domiciliaries, so that the basic in personam jurisdiction was effectively exercizable - as is the case in Barings, albeit that the relief lies in restitution.

As the foregoing analysis of the issues raised in the case has demonstrated, the circumstances by which enrichment actions are both substantive and procedural require the identification and the application of the lex causae and the lex fori for the respective types of issue. The matter of the form of the remedy that is available to the pursuers is unavoidably and self-evidently a matter for the law of the forum in which action is begun for the particular remedy, and it is submitted that the identification of the law by which the consequences of a void contract are ascertainable - the law with which the agreement-derived relationship between the parties is most closely related - may or may not be the parties' supposed lex causae.

\footnotetext{
${ }^{79}$ J.A. Jolowicz in I.R. Scott (ed.), op. cit., at pp. 33-34.

${ }^{80}(1750)$ l Ves. Sen. 444.

${ }^{81}[1969] 2$ Ch. 424.
} 
Effectiveness depends upon the autonomous awarding forum's jurisdictional competence and, to an arguably lesser extent, on the enforcing court(s).

(ix) The issue of effectiveness.

Internationally effective remedies, especially those which accurately reflect the causa established by non-forum law, as the central aim of international administation of civil justice must be as desirable as the conflicts policy of entertaining foreign suit at all, and this is the starting point from which the application of the doctrine of the proper law is to be approached.

\section{APPLICABLE REMEDIAL LAW: OBJECTIVE LOCALIZATION.}

The intersection of "substance" and "remedy" can matter little when the issue is form of relief. Indeed, the interchangeability of "action" and "remedy" should be seen as the basis for coincidents of "jurisdiction" and (remedy-awarding) "judgments" localization pertains to the former, in the sense that it may or may not be jurisdictionally proper for the forum to entertain a cause of action, then it can apply to the latter, in the sense that the remedial considerations in a conflicts case may need to be localized because, without doing so, the matter of relief will be either too domesticized or lost to a predominant lex causae and to want of form. Judicial policy on remedies must of necessity be forum-oriented, lest remedies be issued outwith the forum's jurisdictional competence. It is submitted that it would further an interest in coherent adjudication if conflicts remedies be conceptualized in this way to reflect their jurisdictional foundations.

Further to such a conceptualization, it is worthwhile to recognize the primary (jurisdiction-acquisition), the judgment, and the post-judgment (enforcement) components of remedial jurisdiction, as may be necessary to the particular case. The nomenclature alone is indicative of how remedies conceptually relate to general jurisdiction. But it is important to sacrifice neither the obligational dimensions nor the fact that the forum will never be required to make a formal order unknown to or unprovided for in its own legal system. Nor can it be over-emphasized that, by and large, the terms on which jurisdiction is acquired by a forum will mean that the bulk

${ }^{82} \mathrm{Cf}$. Briggs, loc. cit. An illustration of the point is that under the $1995 \mathrm{Act}$, foreign torts are actionable/justiciable in England insofar as they can be brought within recognized causes of action in England. 
of conflicts cases the forum will determine will not require such gymnastic remedial adjudication as could affirm the viability of "a proper law of a remedy".

Returning to Barings, the Scots law remedy of payment would otherwise have to sustain a right to restitution which sounds in a non-forum (English) proper law, thus harking back to the need to dismantle the unnecessary "fundamental difficulty" cited earlier from the report in the last section of this article, in closing the sub-heading "the restitutionary right to recover'. But recent and current trends (e.g., in the way that the lex loci delicti has in principle superceded dual actionability by section 10 of the 1995 Act as the basis for tort damages as was described in the preceding section of the present paper) make it unwise to rule out now or foreseeably the seductive possibility of restitutionary remedies in the conflict of laws being referred to an objective localization akin to Briggsian jurisdictional propriety ${ }^{83}$ (jurisdictionacquisition and (remedial) judgment), significantly, where all the non-forum law circumstances do not make it inappropriate to do so.

These considerations are not so far removed from Carter's reference, in relation to the old forum-oriented tort conflicts rule, to

"technique[s] of forum control... [the] significance and value [of which are] to be assessed in the context of established (if not always legitimate) forum control techniques of general applicability, such as resort to public policy or the manipulation of the characterization rules" ${ }^{184}$.

It remains to be seen of course whether the exception to the new lex loci delicti rule will be seen to accommodate the referral of remedial issues of a tort conflicts case to its lex delicti as other issues in such cases can now be under section 11 or section 12 of the 1995 Act, public policy permitting ${ }^{85}$. Conflicts remedies need to be conceptualized and articulated in a way that responds to the governing law of the obligation and (or) the law of enforcement.

On any bases - that the pursuers' ultimate entitlement to restitution is subject to Scots forum law, that the law of restitution conflicts is not quite terminologically clear (in that substantive restitution appears to overshadow the description of the

${ }^{83}$ supra, note 82.

${ }^{84}$ P.B. Carter "Choice of Law in Tort and Delict" (1991) 107 L.Q.R. 405, at pp. 408-409.

${ }^{85}$ Cf. the Law Commission Consultation Paper No. 132 (1993), p. 121, para. 5.28, points out the defunct historical antecedents shared by criminal law, the law of tort and the law of remedies. 


\section{PROPER LAW OF A (RESTITUTIONARY) REMEDY?}

considerations at the expense, it would seem, of the remedial issues) or that proper law theory is characteristically unsuited to formal remedies strictly speaking - the better view appears to be that the term at issue will not stand, at least not just yet. The difficulty of want of clarity will persist for example in seeking to relate proper law considerations to non-pecuniary (therefore, non-self-executing) restitution ${ }^{86}$, especially where the place of enforcement of the award (thus, the rules of the restitutional system which obtains there) in such cases is not identifiable when the res judicata award is to be made: e.g., where the place is outside the territorial reach of article 25 of the Brussels Convention which provides for cross-enforceability of judicial orders among the Member States.

The facts in hand indicate Scotland or England as the place of enforcement in the present case, wherein it is difficult to justify the grant of a restitutionary remedy of English law (e.g., recovery of money paid, as in Exall v Partridge ${ }^{87}$ ), qua a possible proper law of the restitutionary obligation. The simple reason is that the action of payment was brought within Scots procedural rules for a restitutionary remedy available in the forum. The forum law which alone may vindicate the right (in the case being discussed, it cannot because the claim is extinguished by prescription, as was mentioned earlier), rather than the English law which, for the reasons given, may assist the establishment of that right, ill-fits the description, as was mentioned earlier), not unless the error identified by Bennett, of "[treating] all enrichment actions as matters of remedy rather than right, or procedure rather than substance "188 is taken to be good law. It is submitted that, as a general but fixed rule, it has not been so taken.

Batthyany $v$ Walford ${ }^{89}$, a case concerning rights running with real property located in Austria (thus, subject to the law of the situs) is authority that the characterization of the cause of action is to be determined by the forum, not necessarily applying its own domestic law categories. The remedy in that case was the forum's restitutionary remedy of account, and it was awarded after the application of Austrian law to the

${ }^{86}$ E.g., restitutionary remedies in rem (cf. the discussion of these remedies by A. Burrows Essays in the Law of Restitution (Oxford: Clarendon, 1993)), pp. 28 et seq.

${ }^{87}$ (1799) 8 T.R. 308; cf. Kleimwort Benson Ltd v Glasgow CC, supra, note 63

88 "Choice of Law Rules in Claims of Unjust Enrichment" 39 I.C.L.Q. 136 (1990), at p. 144.

${ }^{89}$ (1887) 36 Ch. D. 269, especially at pp. 278-279 and 281. The decision has since been followed, e.g, in BP Exploration (Libya) Lid. v Hunt (No. 2) [1979] 1 W.L.R. 783, at pp. 838835 (affirmed [1981] I W.L.R. 232) and in the Chase Manhattan Bank case, supra, note 46. 
cause of action, based on the deterioration of the property, in quasi-contract or implied contract.

Without putting too fine a point on it, Lord Penrose eliminated the apparent bearing of English law in Barings, conveniently applied forum law of jurisdiction and relief as was consistent with his ruling in Morgan and the uniform resolution of the other similar fact cases. His judgment ostensibly accommodates considerations of propriety in the Briggsian sense, and thus presents a blueprint of the quintessence of objective localization: the forum of adjudication is capable of enforcing nonforum rights without necessarily taking the lex causae to be its own law, nor becoming the forum of the legal system to which that law belongs. The remedy of payment would therefore support the entitlement to disgorgement under English law. Alas, the claim was barred by prescription. But this must be seen for what it is: a different misapprehension, of the pursuers', as to actionability, rather than a fallibility in the reasoning that would have applied to the facts if the prescription had been adverted to.

\section{Conclusion.}

In so far as national jurisdictions will be inter-connected only by the rules to which the jurisdictions themselves subscribe, the attractions of the underlying judicial or forum policy of objectivity through the canon of the most significantly related legal system will continue to hold constructive sway. However, it is a misapprehension of the real pragmatic issues if the furtherance of the same policy were prematurely to be submitted to the type of terminology discussed herein. It is a great deal closer to the mark to identify the distinct possibility of the applicable remedial law being comprised of a non-forum lex causae for the availability of the particular relief. It happens that this is the case in which contract conflicts remedies are now to be judicially administered, and even then the reference is to the contractual lex causae or proper law, rather than to the proper law of the remedy; "proper remedies", perhaps, in the absence of distinctive procedures for conflicts cases. Above all, conceptually speaking, remedies and the proper law are best kept separate, even though they may clearly be inter-dependent in particular cases. 